\title{
Celiac crisis in an adult type 1 diabetes mellitus patient: a rare manifestation of celiac disease
}

\author{
Crise celíaca em paciente adulto com diabetes melito \\ tipo 1: uma manifestação rara da doença celíaca
}

Marcos Tadashi Kakitani Toyoshima', Márcia Silva Queiroz', Maria Elizabeth Rossi Silva ${ }^{1,3}$, Maria Lúcia C. Corrêa-Giannella ${ }^{1,2}$, Márcia Nery ${ }^{1}$

1 Divisão de Endocrinologia, Hospital das Clínicas, Faculdade de Medicina, Universidade de São Paulo (HC-FMUSP), São Paulo, SP, Brazil

2 Laboratório de Endocrinologia Celular e Molecular (LIM-25), FMUSP, São Paulo, SP, Brazil

${ }^{3}$ Laboratório de Investigação Médica (LIM-18), FMUSP

São Paulo, SP, Brazil

Correspondence to:

Márcia Nery

Divisão de Endocrinologia, Hospital das Clínicas, Faculdade de Medicina, Universidade de São Paulo

Av. Dr. Enéas de Carvalho Aguiar, 255

$8^{\circ}$ andar

05403-000 - São Paulo, SP, Brazil

marcianery@hcnet.usp.br

\begin{abstract}
SUMMARY
Celiac crisis, an acute severe onset of celiac disease, is a rare and life-threatening manifestation. We report a 30-year-old woman with type 1 diabetes mellitus who arrived at our service with one-month history of severe acute watery diarrhea associated with nausea, vomiting, abdominal pain, and weight loss of $9 \mathrm{~kg}$. The diagnostic hypothesis of celiac crisis was reached based on profuse diarrhea leading to dehydration, severe metabolic and electrolyte abnormalities, and subsequent improvement after introduction of a gluten-free diet. Arq Bras Endocrinol Metab. 2013;57(8):650-2
\end{abstract}

\section{SUMÁRIO}

A crise celíaca é uma manifestação rara e grave da doença celíaca. Relatamos um caso de uma paciente de 30 anos de idade, com antecedente de diabetes melito tipo 1 e história de um mês de diarreia aquosa aguda, associada a náuseas, vômitos, dor abdominal e perda de peso de $9 \mathrm{~kg}$. A hipótese diagnóstica de crise celíaca foi realizada, baseada no quadro de diarreia profusa, desidratação e distúrbios hidroeletrolíticos e ácido-básicos que melhorou após a introdução de dieta enteral sem glúten. Arq Bras Endocrinol Metab. 2013;57(8):650-2

\section{INTRODUCTION}

$\mathrm{C}$ eliac disease $(\mathrm{CD})$ is characterized by impaired immunological response to ingested gluten, and affects $3 \%$ to $8 \%$ of type 1 diabetes mellitus patients (1). Celiac crisis is a rare and life-threatening manifestation, a term that applies to an acute onset or rapid progression of gastrointestinal symptoms that may be attributed to celiac disease. Clinical manifestations include profuse diarrhea leading to dehydration, and metabolic and electrolyte disturbances (hypokalemia, hyponatremia, hypocalcemia, and hypoproteinemia) significant enough to require hospitalization (2-4). The condition mainly affects children under the age of two years, and is very rare in adults. The following report describes a rare case of adult celiac disease presented as a celiac crisis in a type 1 diabetes mellitus patient.

\section{HISTORY AND EXAMINATION}

A 30-year-old woman with a 24-year history of type 1 diabetes mellitus presented one-month history of severe acute diarrhea associated with nausea, vomiting, abdominal pain and weight loss of $9 \mathrm{~kg}$. Stools were in large volume, watery, without blood or mucus, and diarrhea worsened after meals. No fever, blood transfusion or foreign travel was reported. Her diabetes was controlled by basal-bolus insulin therapy: NPH $0.76 \mathrm{IU} / \mathrm{kg}$ and lispro $0.4 \mathrm{IU} / \mathrm{kg}$ plus correction according to pre-prandial glycemia. On admission, she was not febrile, and showed severe dehydration with tachycardia (pulse $100 / \mathrm{min}$ ), blood pressure of $100 / 60 \mathrm{mmHg}$, weight of $55 \mathrm{~kg}$ and height of 160 $\mathrm{cm}$ (BMI: $21.5 \mathrm{~kg} / \mathrm{m}^{2}$ ). Physical examination was otherwise normal. 


\section{INVESTIGATION AND FOLLOW-UP}

Initial laboratorial findings revealed hyperglycemia, metabolic acidosis with ketonemia, hypokalemia, hypomagnesemia, hypocalcemia, and severe hypoalbuminemia (Table 1). HIV status and viral hepatitis serology were negative, and stool examination did not suggest an infectious etiology.

In spite of fluid administration, intravenous insulin infusion, and electrolyte replacement for treatment of diabetic ketoacidosis (DKA), the patient continued to present watery diarrhea and weight loss. Due to severity of the case, empiric antibiotic therapy with metronidazole and ciprofloxacin, and loperamide was prescribed, but no response was observed. Dairy and fatty products were avoided in the diet. Hypoglycemia episodes were frequent, requiring constant reduction in insulin doses; in some meals, only IIU lispro insulin was sufficient to control postprandial glycemia and prevent DKA.

The patient condition worsened with hypokalemia, hypomagnesemia ( $\mathrm{Mg}: 1.4 \mathrm{mg} / \mathrm{dL})$, mild hyponatremia, hypophosphatemia, and hypocalcemia (total serum Ca: $6.1 \mathrm{mg} / \mathrm{dL}$ ), associated with continuous weight loss (body weight $=46 \mathrm{~kg} ; \mathrm{BMI}=18 \mathrm{~kg} / \mathrm{m}^{2}$ ) and malnourishment (albumin: $1.3 \mathrm{mg} / \mathrm{dL}$ ). The patient was therefore started on enteral nutrition. After introduction of enteral nutrition, she showed remarkable improvement and her diarrhea disappeared.

The diagnostic hypothesis of celiac crisis was reached based on the life-threatening manifestation of profuse diarrhea leading to dehydration, severe metabolic and electrolyte abnormalities, and subsequent im- provement following the introduction of a gluten-free diet. The diagnosis was confirmed by levels of serological markers, serum IgA anti-endomysial antibody > 1/1280 (cut-off value: $<1 / 10$ ), and histopathological findings of moderate chronic duodenitis, as well as villous atrophy. After introduction of the gluten-free diet, she gained weight and her insulin dose was increased to a similar amount of insulin she was used to taking.

Her genetic profile showed the HLADRB1*0301/*0402 -DQB1*0201/0302 (-DQ2/ DQ8) and VNTR -INS class I/III genotypes. She did not present the cytotoxic T-lymphocyte antigen-4 (CTLA4) $+49 \mathrm{~A} / \mathrm{G}$ or protein tyrosine phosphatase, non-receptor 22 (PTPN22) 1858C/T gene polymorphisms, which are also linked to type 1 diabetes $(5)$.

\section{DISCUSSION}

Celiac disease is a complex autoimmune disease characterized by a strong genetic association, gluten as a nutritional etiological factor, and the enzyme tissue transglutaminase as an endomysial autoantigen.

CD occurs more frequently in patients with type 1 diabetes than in the general population. Common biological mechanisms, such as autoimmunity-related tissue damage and intolerance to dietary antigens may be etiologic features of both diseases. In Brazil, CD prevalence is $1: 417$ healthy volunteer blood donors (6), whereas it affects $2.6 \%$ to $4.9 \%$ of patients with type 1 diabetes (7). Both diseases are associated with HLA class II genes on chromosome 6p.21.

Table 1. Laboratorial findings on admission, at follow-up before diagnosis of celiac disease, and after a gluten-free diet

\begin{tabular}{lcccc}
\hline Biochemical parameters & Normal range & On admission & $\begin{array}{c}\text { Before celiac disease } \\
\text { diagnosis }\end{array}$ & After gluten-free diet \\
\hline $\mathrm{Na}(\mathrm{mEq} / \mathrm{L})$ & $135-145$ & 134 & 133 & 137 \\
$\mathrm{~K}(\mathrm{mEq} / \mathrm{L})$ & $3.5-5.0$ & 4.5 & 3.3 & 4.5 \\
$\mathrm{Mg}(\mathrm{mg} / \mathrm{dL})$ & $1.58-2.55$ & 1.52 & 1.42 & 1.85 \\
$\mathrm{Cl}(\mathrm{mEg} / \mathrm{L})$ & $98-107$ & $\mathrm{NA}$ & 114 & 111 \\
$\mathrm{HCO}_{3}-(\mathrm{mmol} / \mathrm{L})$ & $20-29$ & $\mathrm{NA}$ & 9.7 & 22 \\
$\mathrm{BUN}(\mathrm{mg} / \mathrm{dL})$ & $10-50$ & 15 & 5 & 9 \\
$\mathrm{Creatinine}(\mathrm{mg} / \mathrm{dL})$ & $0.50-0.90$ & 0.56 & 0.44 & 0.39 \\
Total calcium (mg/dL) & $8.6-10.2$ & 7.3 & 6.1 & 8.4 \\
lonized calcium (mg/dL) & $4.6-5.3$ & 4.7 & 4.7 & 5.1 \\
Phosphorus (mg/dL) & $2.7-4.5$ & 3.3 & 2.8 & 4.6 \\
Albumin (g/dL) & $3.4-4.8$ & 1.9 & 1.3 & 4.3 \\
Hemoglobin (g/dL) & $12-16$ & 12.3 & 11.4 & 13.7 \\
Hematocrit (\%) & $35-47$ & 39.2 & 34.9 & 43.3 \\
\hline
\end{tabular}


More than $90 \%$ of CD patients carry the HLA-DR* 03 $\mathrm{DQAl}^{*} 0501-\mathrm{DQB1}{ }^{*} 0201$ haplotype, and most of the remaining patients have the HLA-DR*04-DQAl *0301$\mathrm{DQBI}{ }^{*} 0302$ haplotype. Our patient expressed both HLA-DR and - DQBI haplotypes.

Approximately half of all CD patients have no overt gastrointestinal symptoms and many are asymptomatic, which may explain the underestimated epidemiologic data in the literature. Between $3 \%$ and $6 \%$ of patients with type 1 diabetes mellitus have (atypical) CD $(1,8,9)$. Celiac crisis is a life-threatening complication of celiac disease, and can be exacerbated in patients with diabetes mellitus $(2,10)$.

Gluten withdrawal with parenteral fluid replacement and nutritional support is the treatment of choice of celiac crisis. For the patients with no prompt response to gluten restriction, treatment with corticosteroids is efficacious (4).

\section{CONCLUSION}

The case described here is an example of the heterogeneous clinical course of celiac disease, never before reported in an adult type 1 diabetes mellitus patient. The high prevalence of CD among individuals with type 1 diabetes mellitus emphasizes the need to consider celiac crisis as a differential diagnosis of diabetic adults suffering from acute diarrhea and acidosis.
Disclosure: no potential conflict of interest relevant to this article was reported.

\section{REFERENCES}

1. Schuppan D, Hahn EG. Celiac disease and its link to type 1 diabetes mellitus. J Pediatr Endocrinol Metab. 2001;14(Suppl. 1):597-605.

2. Baranwal AK, Singhi SC, Thapa BR, Kakkar N. Celiac crisis. Indian J Pediatr. 2003;70:433-5.

3. Lloyd-Still JD, Grand RJ, Khaw KT, Shwachman H. The use of corticosteroids in celiac crisis. J Pediatr. 1972;81:1074-81.

4. Jamma S, Rubio-Tapia A, Kelly CP, Murray J, Najarian R, Sheth $S$, et al. Celiac crisis is a rare but serious complication of celiac disease in adults. Clin Gastroenterol Hepatol. 2010;8:587-90.

5. Jahromi MM, Eisenbarth GS. Cellular and molecular pathogenesis of type 1A diabetes. Cell Mol Life Sci. 2007;64:865-72.

6. Pereira MA, Ortiz-Agostinho $\mathrm{CL}$, Nishitokukado I, Sato $\mathrm{MN}$, Damiao AO, Alencar ML, et al. Prevalence of celiac disease in an urban area of Brazil with predominantly European ancestry. World J Gastroenterol. 2006;2:6546-50.

7. Silva ME, Mory D, Davini E. Genetic and humoral autoimmunity markers of type 1 diabetes: from theory to practice. Arq Bras Endocrinol Metabol. 2008;52:166-80.

8. Dieterich W, Esslinger B, Schuppan D. Pathomechanisms in celiac disease. Int Arch Allergy Immunol. 2003;132:98-108.

9. Schuppan D. Current concepts of celiac disease pathogenesis. Gastroenterology. 2000;119:234-42.

10. Mones RL, Atienza KV, Youssef NN, Verga B, Mercer GO, Rosh JR. Celiac crisis in the modern era. J Pediatr Gastroenterol Nutr. 2007;45:480-3. 